\title{
Management of Character Education (Analysis on Students at Unima Sociology Education Study Program)
}

\author{
Yoseph Daniel Ari Santie* \\ Sociology Educational Department \\ Faculty of Social Science \\ Universitas Negeri Manado \\ Manado, Sulawesi Utara \\ yosephsantie17@yahoo.com
}

\author{
Romi Mesra \\ Sociology Educational Department \\ Faculty of Social Science \\ Universitas Negeri Manado \\ Manado, Sulawesi Utara \\ romimesra@unima.ac.id
}

\author{
Paulus Robert Tuerah \\ Study Program Social Science \\ Education \\ Faculty of Social Science \\ Universitas Negeri Manado \\ Manado, Sulawesi Utara \\ paulustuerah@unima.ac.id
}

\begin{abstract}
The Indonesian nation is a large nation, with a population of around $\mathbf{2 4 0}$ million people, occupies the fourth position in the world, but has very complex and serious problems, such as the fragility of commitment to the basic values of life that are becoming guidelines, which we know as views nation's life. According to the national policy master book, the building of the character of the Indonesian nation in 2010-2025, there are 6 factors of national problems that lie behind the waning of character education, namely: (1) disorientation and not living up to Pancasila values; (2) the limitations of the integrated policy of integrated policy in realizing the values of Pancasila; (3) shifting ethical values in national life; (4) waning awareness of cultural values; (5) the threat of national disintegration; (6) the weakening of national independence. The young generation which is currently referred to as the next generation of the nation including students who are agents of change have a very strategic place in the development of human resources in the future, but there are still doubts after observing the current developments, it is allegedly at this level that the perpetrators of values are deviated. these magic values. By directly observing the behavior of students

have attitudes and behavior in accordance with the rules that apply in society. But the fact is not in line with expectations, due to the inconsistency of students to behave and behave according to the agreed standard guidelines, as well as low learning discipline as well. The application of management functions to students of Unima's sociology education study program is carried out using a qualitative approach with a focus on the problem, namely: (a) how to plan learning, (b) how to organize learning, (c) how to actualize learning, (d) how to supervise (controlling) learning. Research data collection was carried out by interview and questionnaire to the informants. For this reason, the aim of the research is to answer the problem of applying management functions, namely: the planning function, the organizing function, the actualization function and the supervisory function. The results showed that all management functions have been implemented, but have not been accompanied by good learning discipline, learning planning that suits your needs, and optimal learning enthusiasm. As a result, learning outcomes have not been reached optimally because they are not in accordance with the goals and objectives and expectations.
\end{abstract} at this time it is certainly our responsibility to find solutions to behavior deviations that if left unchecked will become a time bomb that will at any time explode and destroy the future of our beloved nation. Managing student attitudes and behaviors (characters) requires reliable management, absolutely accompanied by implementing good management functions, namely: (a) managerial functions, in the form of planning, organizing, mobilizing and controlling functions; (b) operational functions in the form of: procurement, development, compensation, integration, maintenance and termination of employment; (c) management position functions in the form of; achievement of organizational or institutional goals [1]. Management is an alternative solution to guide people to behave and act. To mobilize human attitudes and behavior in order to achieve its objectives, a good and correct management approach is needed, starting from planning (planning) good and measurable planning, (organizing) organizing involving all components, (actuating) actualizing all planned activities optimally, and (controlling) evaluate carefully and thoroughly all of their behaviors and attitudes, whether resolved well or experiencing problems and not resolved properly. Thus the achievement of goals and objectives of good student attitudes and behavior is largely determined by its management based on the agreed upon attitudes and behavioral guidelines. This applies also to students of the Unima sociology education program, who are expected to

\section{Keywords: Management, Character Education}

\section{INTRODUCTION}

The word of management comes from the word to manage which means to regulate [2], thus management is a process to realize desired goals. The definition of regulating has meaning that is through a process of order of management functions, namely: planning, organizing, directing, and controlling. According to [3] management is the process of planning, organizing, managing resources, communicating, leading, motivating, and controlling the implementation of tasks, and the use of resources to achieve organizational goals effectively and efficiently. According to Stoner and Winkel in reference [4], that management is the process of planning, organizing, leadership, and controlling the efforts of organizational members and the use of all other organizational resources for the achievement of organizational goals.

Management functions according to experts vary, but have similarities, such as the opinion of reference [5] below: 


\begin{tabular}{|l|l|l|l|}
\hline G. R. Terry & $\begin{array}{l}\text { John } \\
\text { Mee }\end{array}$ & Louis Allen & Mc. Namara \\
\hline Planning & Planning & Leading & Planning \\
\hline Organizing & Organizing & Planning & Programming \\
\hline Actuating & Motivating & Organizing & Budgeting \\
\hline Controlling & Controlling & Controlling & System \\
\hline
\end{tabular}

\begin{tabular}{|l|l|l|l|}
\hline Henry Fayol & $\begin{array}{c}\text { Harold } \\
\text { Koonts \& } \\
\text { Cyril } \\
\text { O’Donnel }\end{array}$ & $\begin{array}{c}\text { S. P } \\
\text { Siagian }\end{array}$ & \multicolumn{1}{|c}{ Oey Liang Lee } \\
\hline Planning & Planning & Planning & Perencanaan \\
\hline Organizing & Organizing & Organizing & Pengorganisasian \\
\hline Commanding & Staffing & Motivating & Pengarahan \\
\hline Coordinating & Directing & Controlling & Pengkoordinasian \\
\hline Controlling & Controlling & Evaluating & Pengontrolan \\
\hline
\end{tabular}

\begin{tabular}{|l|l|l|l|}
\hline W.H.Newman & \multicolumn{1}{|c|}{$\begin{array}{c}\text { Luther } \\
\text { Gullick }\end{array}$} & $\begin{array}{c}\text { Lyndall F. } \\
\text { Urwick }\end{array}$ & $\begin{array}{c}\text { John D. } \\
\text { Millet }\end{array}$ \\
\hline Planning & Planning & Forecasting & Directing \\
\hline Organizing & Organizing & Planning & - \\
\hline $\begin{array}{l}\text { Assembling } \\
\text { Resources }\end{array}$ & Staffing & Organizing & Facilitating \\
\hline Directing & Directing & Commanding & - \\
\hline Controlling & Coordinating & Coordinating & - \\
\hline- & Reporting & Controlling & - \\
\hline- & Budgeting & - & - \\
\hline
\end{tabular}

\section{RESEARCH METHODS}

This research was conducted on students of the Unima sociology education study program, which aims to examine (a) how the study plan and academic life and lecture process, (b) how to organize learning and academic life and the lecture process, (c) how to actualize learning and academic life and the lecture process, (d) how to supervise (controlling) learning and academic life and the lecture process. The method used is qualitative, namely to understand the symptoms experienced by research subjects, in the form of behavior and action holistically by describing empirical experiences [6].

The focus of research is the management of character education in Unima's sociology education study program students, with data collection techniques in the form of participatory observation, in-depth interviews, and then the data are analyzed using Miles and Huberman's analytical techniques in reference [7], namely: 1. Data Reduction (the data obtained is recorded and then reduced to get the things that are important). (2) Data Presentation (presenting data to understand what is happening). (3) Draw Conclusions.

\section{RESULT AND DISCUSSION}

The results of this study describe the qualitative data, which are the results of interviews with informants, as below: schedule I use as much discipline and as much as possible let alone do the assignments and before the test / exam both mid and semester exams due to experience in the last even semester my grade point average was close

1. Planning. (Are learning activities and academic life

From the results of the interview with the first informant, namely - The first semester class (AG) leader provides information and data that in conducting a learning plan based on a learning plan that has been prepared at the beginning of the semester, but there are also learning activities that need to be adapted to the situation and existing conditions, namely the dynamics of us life, such as public lectures, seminars at the university / faculty level. All plans are always carried out well, although it must be admitted there are still learning plans that are constrained due to changes in schedule of aetivities.

The second informant is the Class Chair III semester IG) said that the learning plan that has been prepared nd formulated in this odd semester in the form of a study to 4.0. In general, the plans I put together and carry out with discipline have a positive impact on the results or values that I get.

The fourth informant, namely the class head of the fifth semester (NK), suggested that I had compiled a learning plan and set it at the beginning of this odd semester through careful consideration based on the experience of previous semesters, although this seemed monotonous, because it was inflexible, but helped achieve goals I namely there are no subjects that fail, although it is undeniable that there are also learning activities that are not planned carefully so that the impact on results is not optimal.

The fifth informant, I believe the class leader VII semester (FT), said that all of my learning plans in this odd semester I have programmed well, and with as much as possible I use, although sometimes there are still temptations from friends who ignore these plans, because the invitation of friends to spree, as a result the values that I get are less satisfying.

\section{Organizing (Are learning activities, academic life and lecturing processes well organized?)}

The head of the first semester class (AG) provides information and data that in carrying out learning activities, the lecture process and academic life, both on campus and in the boarding house, always carried out well, although it must be admitted that there are still constrained (unorganized) college plans due to schedule changes, or being unable to attend due to illness.

The second informant, the class leader of the third semester (MG), said that the organization of lecture activities went well because the lecture process was in accordance with the schedule and the lecturer was very disciplined in giving lectures, while the completion of assignments and activities in the boarding house experienced disruption due to unfavorable learning conditions. and lecture processes carried out based on planning?). 
The third informant, namely the leader of the 5th semester class (NK), stated that all activities on campus were well-organized and well-scheduled, although there were also sudden activities that had to be carried out without being well-organized because there were good guest lectures at the university level, faculty or graduation activities, dies natalis and other activities on campus that require lectures and other learning activities to be disrupted.

The fourth informant, the class leader VII semester (FT), stated that almost all activities planned on campus were organized by the head of the faculty / vice dean of the academic field, and student activities by the vice dean of student affairs, although this was not optimal, it helped to achieve planned activities on campus. There are also activities that are not well-organized that have an impact on outcomes that are not optimal.

\section{Actualization (Are learning activities, academic life and lecturing processes carried out well?)}

The informant who represented the first semester, namely the class leader (AG), provided information and data that the lecture activities on campus were running well because both faculty leaders, lecturers and students supported each other, the responsibilities of each component could create a good academic atmosphere. although it must be admitted that there are still good lecturers, students who have not carried out their responsibilities in full.

The second informant, namely the class chair III semester (MG) said that the lecture activation in the study program of sociology, especially odd semester (III) which was well programmed (KRS) according to the schedule was running well, starting with the implementation of a good lecture by each lecturer, followed with discipline by students who contract each course, this greatly helps the learning climate of every student.

The third informant, namely the class head of semester V, (NK), stated that all lecture activities, other student activities (extracurricular) and other student activities were already good, although there were still a small number of students who were still lacking discipline in their academic activities due to lack of motivation and lack of focus in learning.

The fourth informant, the class leader VII semester (FT), gave a response about the activation of student activities, lectures, and academic atmosphere in the sociology education study program that has been going well, especially in semester VII, in contrast to the lower semesters where attitudes and disciplines learning is still not serious and focused, but entering the final semester, motivation and attitude and learning discipline are very good. As proof that with good grades, there are even students who have contracted thesis seminar courses, so that the lecture period is only a test result.

\section{Supervision (Are learning activities, academic life and lectures controlled / supervised well?)}

The head of the first semester class (AG) provides information and data that in carrying out lecture activities, learning activities and other student activities in general are only controlled through the study plan card, (KRS) only, while other activities are not well controlled because it is still at the stage of adaptation to the environment new, this has an impact on test scores that not all students have good grades, so also academic attitudes and behavior are not optimal because of self control that is not focused.

The second informant, the class leader III semester (MG) gave a response about supervision in learning activities, academic life and the lecture process, not in line with expectations, which has a good attitude in learning, discipline and full responsibility in learning, all of this is caused by there is still a lack of learning control and poor attitude.

The leader of the fifth semester class as an informant (NK), said that the supervision in the fifth semester students, starting at learning activities, both on campus and in the boarding house, has been going well, but not yet evenly distributed to all students, indifferent attitude and less serious in all student academic activities are still weak, this is because no one is supervising all academic activities in full, there is only supervision activities on campus during lectures, while other activities are not there.

The fourth informant is the class leader VII semester (FT), provides answers and data about student supervision in learning activities / lectures on campus, other academic activities, this may be influenced by the level of maturity and end of study so that almost all students in semester VII have an adult attitude in all academic activities on campus, as well as activities in the boarding house, on average all students compete to complete their studies, because in addition to selfmotivation, so also the supervisor is very functioning to encourage students to complete their studies on time.

From the data and research results above, it shows that almost all academic activities of sociology education study program students both on campus and at boarding (outside campus) have been carried out in accordance with management functions, that is, based on careful planning, well-organized, well actualized, but not yet actualized controlled / supervised optimally, so that it has not given maximum results, namely the objectives of all learning activities and academic atmosphere have not been achieved as expected.

Theoretical studies used in this study are: reference [2] research results that the planning function is an important basic function to achieve organizational goals, because without planning it means there are no goals to be achieved, a lot of waste, control cannot be done. Furthermore according to reference [8] planning is the process of preparing activities systematically to be carried out to achieve goals. Development activities and activities in the village are the responsibility of the 
government and community members, beginning with joint planning.

Then according to George Terry in reference [5] stated: "Actuating is setting all members of the group to want to achieve and to strike to achieve the objective willingly and keeping with the managerial planning and organizing efforts". (actualization is to make all group members want to cooperate and work sincerely and are passionate about achieving goals in accordance with planning and organizing efforts.

Furthermore, according to reference [5] the function of control or supervision is crucial in the implementation of the management process, because it must be done as well as possible. Control or control is the process of determining what must be achieved, and if necessary make improvements so that the implementation according to a plan in harmony.

\section{CONCLUSION}

Based on the analysis of the results of the research above, the findings of this study are: Learning activities, attitudes and behavior of students in learning and disciplines ranging from planning, implementing, organizing and supervising / controlling in all student academic activities even though they have been carried out according to management functions, namely has used planning, has used organizing, has used actualization, and has used control or supervision, but it has not been maximally carried out so that the results of the goals set have not been realized properly.

\section{ACKNOWLEDGMENT}

The author would like to thank: Unima's Rector who helped researchers give permission to conduct research and specifically to the Dean of FIS Unima who has contributed in completing this research to completion.

\section{REFERENCES}

[1] P. R. Tuerah, Yoseph Daniel Ari Santie, A. L. Lonto, and T. Pangalila, 'Character Education on Students in Social Science Faculty at Manado State University', in 1st International Conference on Education, Social Sciences and Humanities (ICESSHum 2019), 2019, vol. 335, no. ICESSHum, pp. 512-517.

[2] S. P. Hasibuan, Manajemen Dasar-Pengertian dan Masalah. Jakarta: Bumi Aksara, 2006.

[3] U. Silalahi, Azas-azas manajemen. Bandung: Rafika Aditama, 2011.

[4] H. B. Siswanto, Pengantar Manajemen. Jakarta: Bumi Aksara, 2010.

[5] Afifuddin, Dasar Manajemen. Bandung: Alfabeta, 2013.

[6] L. J. Moleong, Metodologi Penelitian Kualitatif. Bandung: Remaja Rosdakarya, 2011.

[7] Sugiyono, Metode Penelitian Kombinasi (Mixed Methods). Bandung: Alfabeta, 2016.

[8] B. Tjokroamidjojo, Pengantar administrasi pembangunan. Lembaga Penelitian, Pendidikan dan Penerangan Ekonomi dan Sosial, 1974. 